\title{
Fertilization and Irrigation Affect Soil Carbon under Eucalyptus Plantation in the Cerrado
}

\author{
Ricardo Cardoso Fialho ${ }^{1}$ (D), Rafael da Silva Teixeira ${ }^{1}$ (D), \\ Ana Paula Mendes Teixeira ${ }^{1}$ (D), Thalles Guimarães Reis ${ }^{1}$ (D), \\ Ivo Ribeiro da Silva ${ }^{1}$ \\ ${ }^{1}$ Universidade Federal de Viçosa (UFV), Viçosa, MG, Brasil
}

\begin{abstract}
This study aimed: i) to evaluate the influence of fertilization and irrigation management on eucalyptus plantations for soil carbon (C) dynamics; ii) to evaluate the impact of fertilization and irrigation management on eucalyptus plantations in the $\mathrm{C}$ allocation in depth compared to the Cerrado biome. This study was carried out in an eucalyptus plantation at the end of the third rotation (7 years), which received different fertilizations and irrigations, and a Cerrado area was used as reference. Soil samples were collected in trenches and the gases $\left(\mathrm{CO}_{2}\right.$ and $\left.\mathrm{CH}_{4}\right)$ on the surface. The total organic carbon (TOC) is more influenced by the availability of water than nutrients. Soils under eucalyptus stands are more efficient at $\mathrm{C}$ stocks in depth than the Cerrado and act as a liquid drain of $\mathrm{CO}_{2}$ and $\mathrm{CH}_{4}$ from the atmosphere.
\end{abstract}

Keywords: $\mathrm{CO}_{2}, \mathrm{CH}_{4}$, carbon management index, planted forests. 


\section{INTRODUCTION AND OBJECTIVES}

The current scenario of global climate change has awakened the interest of the scientific community in the elaboration of strategies that seek to mitigate greenhouse gases (GHG) emissions and increase C sequestration, especially in systems that give greater stability like the soil (IPCC, 2014). In Brazil, agriculture is responsible for a large part of the emissions of the main GHGs $\left(\mathrm{CO}_{2}, \mathrm{CH}_{4}\right.$ and $\left.\mathrm{N}_{2} \mathrm{O}\right)$, due to deforestation and intensive soil management. However, this scenario has been currently altered by the reduction of deforestation and the recovery of degraded areas (Hansen et al., 2013; Inpe, 2015).

Eucalyptus planted forests show rapid growth and high resource efficiency, which results in a large accumulation of biomass, both in the aerial part and in the root system of the plant (Stape et al., 2010). This high efficiency gives these effective forests potential to sequester atmospheric $\mathrm{CO}_{2}$ with subsequent $\mathrm{C}$ stabilization in the soil compartments when the plant residues are added to the soil (Gatto et al., 2010). Turner et al. (2005), evaluating the Eucalyptus grandis plantations aged 0-35 years in Australia, found a decrease in the soil organic carbon (SOC) and affirmed that this trend occurs until the end of the forest cycle. In Brazil, Zinn et al. (2002) found SOC losses under initial eucalyptus plantation in relation to the Cerrado. These authors found recovery of SOC at the end of the second rotation, led by regrowth (Zinn et al., 2011). Fialho \& Zinn (2014), in a meta-analysis about the potential of $\mathrm{C}$ accumulation in soils under eucalyptus and native vegetation in Brazil, did not find significant changes in the SOC content and stocks under eucalyptus when compared to native vegetation. These authors found that even at more advanced ages, no trends for SOC accumulation are observed and SOC losses associated with eucalyptus cultivation are not a concern. Thus, it is not clear how the $\mathrm{C}$ dynamics occur and if the accumulation or losses are favored during the cultivation of eucalyptus forests.

Management techniques that provide less soil revolving, higher root/aerial part ratio (Rasse et al., 2005) and higher productivity (Gatto et al., 2011) may contribute to a greater accumulation of SOC. In addition, physical and chemical processes restrict the microbial decomposition of COS in depth, increasing its permanence in the system and consequent stabilization (Bernal et al., 2016; Schmidt et al., 2011). So, the studies which approach the $\mathrm{C}$ evaluation in depth are of greater relevance when aimed at management strategies that favor a greater $\mathrm{C}$ sequestration in soil. However, studies in Brazil that evaluate the SOC allocation at greater depths are scarce.

The SOC accumulation can be influenced by climatic factors such as water deficit which is the most limiting to obtain high yields for eucalyptus (Gatto et al., 2010; Stape et al., 2004).

However, the cultivation of forest species with higher availability of water and/or fertilizers may provide increased productivity (Stape et al., 2004) and consequent plant litter input to soil, $\mathrm{C}$ allocation in the root system (Lai et al., 2016), as well as changes in soil microbial activity. Fertigated cultivation has been shown to be more effective in increasing $\mathrm{C}$ and $\mathrm{N}$ in soil (Li et al., 2007), possibly by narrowing the $\mathrm{C}: \mathrm{N}$ ratio and favoring the SOC stabilization (Forrester et al., 2006).

This study aimed to evaluate the influence of fertilization and irrigation management in eucalyptus plantations for soil C dynamics and the impact of fertilization and irrigation management on eucalyptus plantations in the $\mathrm{C}$ allocation in depth compared to the Cerrado biome.

\section{MATERIALS AND METHODS}

\subsection{Characterization of the study area}

The study was carried out in eucalyptus plantations (Eucalyptus urophylla $\times$ Eucalyptus grandis; $3 \times 3 \mathrm{~m}$ spacing) at the end of the third rotation (7 years), located in the region of Bocaiúva, MG (17 $20^{\circ}$ 'S and $43^{\circ} 50^{\prime} \mathrm{W}, 900 \mathrm{~m}$ of elevation). The average annual temperature is $23.6^{\circ} \mathrm{C}$ and the average annual rainfall is $848 \mathrm{~mm}$, with dry season well accented. In addition to the areas with eucalyptus, the native Cerrado was evaluated as a reference. The soil is classified as clayey dystrophic Red Latosol (Stape et al., 2010).

\subsection{Treatments and experimental design}

Five treatments (CN, CI, FN, FI and Cerrado) were set up in a randomized block design with three 
replications. Treatments were arranged in a split-plot in time design that consisted of: i) $\mathrm{CN}$ : with conventional fertilization (C - N: 79; P: 55; K: 66; Ca: 280; Mg: 60; and B: $\left.6 \mathrm{~kg} \mathrm{ha}^{1}\right)+$ without irrigation (N); ii) CI: with conventional fertilization $(\mathrm{C})+$ with irrigation (I - irrigation by spraying, with a mean blade water of $22.5 \mathrm{~mm}$ applied twice a week in the total area); iii) FN: with potential fertilization ( $\mathrm{F}-\mathrm{N}$ : 444; P: 160; K: 369; Ca: 280; Mg: 60; and B: $8 \mathrm{~kg} \mathrm{ha}^{1}$; divided into three applications during the first three years) + without irrigation (N); iv) FI: with potential fertilization (F) + with irrigation (I); v) Cerrado: native forest as reference.

\subsection{Gas collection, litter and soil analysis}

Gas and soil sampling were performed in July 2014, and irrigation management was interrupted for approximately one year. In each treatment were opened six trenches of $1 \mathrm{~m}^{3}$, being three rows $(\mathrm{R})$ and three inter-row (IR). Deformed and undisturbed soil samples were collected in the layers $0-10,10-20,20-40$, 40-60 and 60-100 $\mathrm{cm}$ of depth.

For the evaluation of the GHGs, static chambers (PVC columns; $0.2 \mathrm{~m}$ in height and $0.3 \mathrm{~m}$ in diameter) were installed in the soil, reaching a depth of $0.05 \mathrm{~m}$, in each $\mathrm{R}$ an IR location. At the time of sampling, the chambers were sealed with PVC caps, fitted with a rubber septum to prevent air passage from the soil to the open atmosphere and to allow measurement of changes concentration of gases over collection time. The gases were collected at intervals of 0,10 , 20, 40-minute after sealing the chambers, using 60-ml syringes equipped with three-way valves for further determinations of $\mathrm{CO}_{2}$ and $\mathrm{CH}_{4}$ using the Cavity Ring Down Spectroscopy - CRDS (Picarro, Sunnyvalle, CA).

The Equation 1 was used to calculate the gas fluxes (Smith \& Conen, 2004).

Soil $\mathrm{CO}_{2}$ or $\mathrm{CH}_{4}$ flux $\left(\mathrm{mg} \mathrm{m}^{-2} \mathrm{~h}^{-1}\right)=$

$\left(\frac{" \mathrm{Q}}{” \mathrm{t}}\right) \times \mathrm{M} \times\left(\frac{\mathrm{P} \times \mathrm{V}}{\mathrm{R} \times \mathrm{T}}\right) \times\left(\frac{1}{\mathrm{~A}}\right) \times 3,6$

$\Delta \mathrm{Q} / \Delta \mathrm{t}$ : angular coefficient (ppm s $\mathrm{s}^{1}$ ) obtained by adjusting the gas concentrations over time; M: molar mass of the gas $\left(\mathrm{g} \mathrm{mol}^{1}\right)$; $\mathrm{P}$ : constant pressure of $1 \mathrm{~atm}$; V: chamber volume (L); R: gas constant (0.08205746); T: temperature in the soil $(\mathrm{K})$; A: chamber area $\left(\mathrm{m}^{2}\right)$; 3.6: units adjustment factor for $\mu g \mathrm{~m}^{2} \mathrm{~s}^{1}$ to $\mathrm{mg} \mathrm{m}^{2} \mathrm{~h}^{1}$.
The soil temperature and the soil moisture in the 0 to $0.05 \mathrm{~m}$ soil layer were measured using an EC-5 sensor (Decagon Devices Inc., Pullman, WA, USA) at the time of gas collection. The litter samples were collected randomly with a $0.5 \times 0.5 \mathrm{~m}$ template, dried at $60^{\circ} \mathrm{C}$ in a forced-air circulation oven until constant weight, which is done for further quantification of the dry mass (Figure 1c).

Soil sub-samples were air dried and passed through 100 mesh sieves to determine the total organic carbon (TOC) and total nitrogen (TN) contents by the dry combustion method in CHNS (Analyzer 2400 series II, Perkin Elmer Company), and the oxidizable carbon (Labile C) content according to methodology described by Shang \& Tiessen (1997).

The TOC, TN and Labile-C stocks were estimated through the equations 2, 3, 4 and 5 described below, adapted from Ellert \& Bettany (1995):

$\mathrm{SM}=\mathrm{D}\left(\mathrm{Mg} \mathrm{m}^{-1}\right) \times \mathrm{VL}\left(\mathrm{m}^{3}\right)$

$\mathrm{Ma}=\left(\mathrm{SM}_{\text {ref }}-\mathrm{SM}\right)$

$\mathrm{SM}_{\text {equiv }}=\mathrm{Ma}+\mathrm{SM}$

$\mathrm{ST}_{\mathrm{C}, \mathrm{N} \text { or } \mathrm{C}_{\text {labile }}}\left(\mathrm{Mg} \mathrm{ha}^{-1}\right)=\frac{\mathrm{Con}_{\mathrm{C}, \mathrm{N} \text { or Cl }} \text { abile }_{\text {e }}}{\mathrm{SM}_{\text {equiv }}}$

SM: soil mass; D: soil density in $\mathrm{Mg} \mathrm{m}^{3}$ (Table 1); VL: layer volume $\left(\mathrm{m}^{3}\right)$; Ma: mass added; $\mathrm{SM}_{\text {ref }}$ : soil mass reference that presents greater density; $\mathrm{SM}_{\text {equiv }}$ : equivalent mass; $\mathrm{ST}_{\mathrm{C}, \mathrm{N} \text { or Labilec }}$ : TOC, TN or Labile-C stocks; Con ${ }_{\mathrm{C}, \mathrm{N} \text { or Labilec }}$ : TOC, TN or Labile-C contents.

The stocks per hectare in the eucalyptus plantations weights were made of the area occupied by R and IR (Equation 6).

$\operatorname{STtotal}_{\mathrm{C} . \mathrm{N} \mathrm{or} \mathrm{C}_{\text {labile }}}\left(\mathrm{Mg} \mathrm{ha}^{-1}\right)=$

$\left(\left(\frac{1}{3}\right) \times \mathrm{ST}_{\mathrm{R}}\right)+\left(\left(\frac{2}{3}\right) \times \mathrm{ST}_{\mathrm{IR}}\right)$

Moreover, the Carbon Management Index (CMI) was calculated (Blair et al., 1995) as shown on Equation 7.

$\mathrm{CMI}(\%)=\mathrm{CCI} \times \mathrm{IL} \times 100$

Where CCI is the carbon compartment index given by the ratio of TOC of the cultivated area and TOC of the reference area (Equation 8). 
Table 1. Soil density for different treatments at depths of 0-10, 10-20, 20-40, 40-60 and 60-100 cm.

\begin{tabular}{cccccccccccc}
\multirow{2}{*}{ Depth } & Cerrado & \multicolumn{2}{c}{ CN } & \multicolumn{2}{c}{ FN } & \multicolumn{2}{c}{ CI } & \multicolumn{2}{c}{ FI } \\
\cline { 3 - 10 } & & R & IR & R & IR & R & IR & R & IR \\
$0-10$ & 1.05 & 0.89 & 0.86 & 0.78 & 0.81 & 0.79 & 0.82 & 0.81 & 0.83 \\
$10-20$ & 1.07 & 0.80 & 0.86 & 0.80 & 0.81 & 0.80 & 0.83 & 0.88 & 0.79 \\
$20-40$ & 1.01 & 0.84 & 0.89 & 0.82 & 0.83 & 0.85 & 0.87 & 0.87 & 0.84 \\
$40-60$ & 1.11 & 0.82 & 0.84 & 0.78 & 0.78 & 0.88 & 0.87 & 0.87 & 0.87 \\
$60-100$ & 0.96 & 0.84 & 0.87 & 0.85 & 0.84 & 0.82 & 0.80 & 0.84 & 0.84 \\
\hline
\end{tabular}

Depth in cm; R: plant rows; IR: plant inter-row; CN: eucalyptus cultivation with conventional non-irrigated fertilization; CI: eucalyptus cultivation with irrigated conventional fertilization; FN: eucalyptus cultivation with potential fertilization, not irrigated; FI: eucalyptus cultivation with irrigated potential fertilization.

$\mathrm{CCI}=\frac{\mathrm{TOC}_{\text {euc }}}{\mathrm{TOC}_{\text {Cerrado }}}$

The LI is the lability index given by the ratio of $\mathrm{C}$ lability of cultivated area and C lability of the reference area, where $\mathrm{C}$ lability is given by the ratio of Labile- $\mathrm{C}$ to Non-labile-C (Equation 9).

$\mathrm{LI}=\frac{\mathrm{L}_{\text {euc }}}{\mathrm{L}_{\text {Cerrado }}}$

In turn, the $\mathrm{L}$ values represents the $\mathrm{C}$ lability, being calculated according to Equation 10.

$\mathrm{L}=\frac{\text { Labile-C }}{\text { Non-labile-C }}$

Where Non-labile-C is the difference between TOC and Labile-C.

\subsection{Statistical analysis}

The data were subjected to analysis of variance (Anova) and the Post-hoc Tukey's test $(\alpha=0.10)$. The partitioned TOC values were compared by the Dunnett's test $(\alpha=0.05)$, where each treatment is compared to a predetermined reference, in the case of the Cerrado. The statistical analyses were performed using Statistica 12.0 software (Stat soft Inc., Tulsa, USA).

\section{RESULTS}

\section{1. $\mathrm{CO}_{2}$ and $\mathrm{CH}_{4}$ fluxes}

Soil $\mathrm{CO}_{2}$ effluxes were observed for all treatments (Figure 1). The Cerrado had the highest $(p<0.1){\text { soil } \mathrm{CO}_{2}}$ emissions, about $148 \mathrm{mg} \mathrm{m}^{2} \mathrm{~h}^{1}$, while the eucalyptus soil emissions ranged from 117 to $57 \mathrm{mg} \mathrm{m}^{-2} \mathrm{~h}^{-1}$ (Figure 1). Eucalyptus soil emissions presented differences regarding the position (R and IR) of the gas evaluation (Figure 1) and the evaluated treatments. The soils under eucalyptus without irrigation ( $\mathrm{CN}$ and $\mathrm{FN}$ ) presented the highest $\mathrm{CO}_{2}$ efflux values in the $\mathrm{R}$ when compared to the IR. For the treatments that received irrigation (CI and FI), the inverse was verified (Figure 1).

In relation to the $\mathrm{CH}_{4}$, all soils provided a $\mathrm{CH}_{4}$ inflow independent of the treatments (Figure 1); the soil behaved as a drain of atmospheric $\mathrm{CH}_{4}$. Some difference $(p<0.1)$ in the position of collection of the evolved gases of the soil was also verified when considering the $\mathrm{CH}_{4}$ influx (Figure 1). The soil under non-irrigated eucalyptus $\left(\mathrm{CN}\right.$ and $\mathrm{FN}$ ) provided the highest $(p<0.1) \mathrm{CH}_{4}$ influx in the $\mathrm{R}$ when compared to the Cerrado and irrigated eucalyptus (CI and FI) (Figure 1).

\subsection{Soil carbon and nitrogen stocks}

TOC stocks differences were not verified $(p>0.1)$ in the $0-10$ and $10-20 \mathrm{~cm}$ soil layers. To the subsurface soil layers $(20-40$ to $60-100 \mathrm{~cm})$ the inverse is verified, the soil under eucalyptus (independent of irrigation) presented larger TOC stocks than the soil under Cerrado, differing statistically $(p<0.1)$ (Table 2$)$.

TN did not present statistical difference $(p>0.1)$ between treatments (Table 2). The soil C:N ratio under eucalyptus differ $(p<0.1)$ from the Cerrado only in the $0-10 \mathrm{~cm}$ soil layer (Table 2 ), while the others did not differ among themselves $(p>0.1)$.

Partitioning TOC stocks of the soil profile $(0-100 \mathrm{~cm})$ in Labile-C and Non-labile-C, it is verified that all treatments 

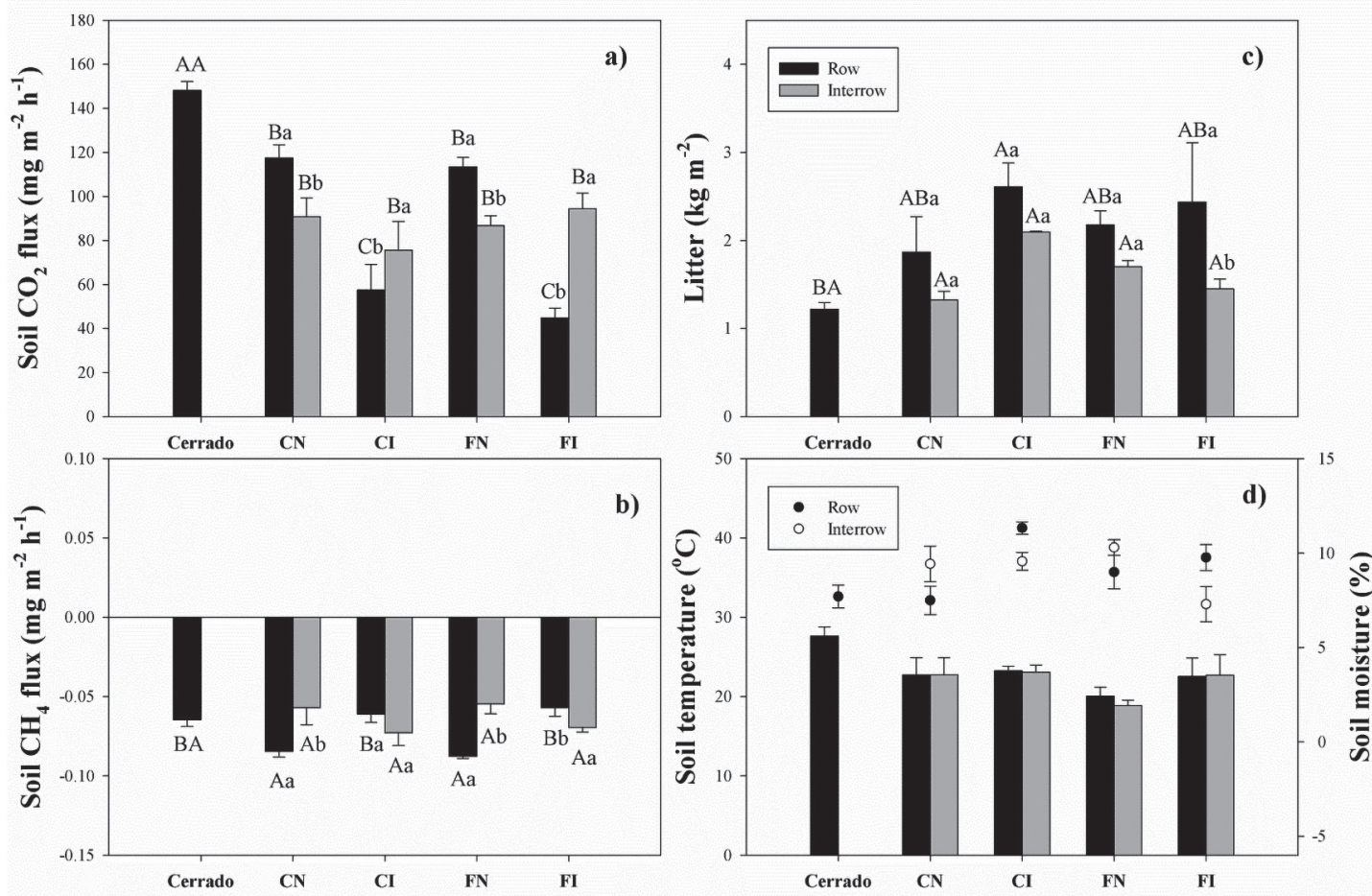

Figure 1. Soil $\mathrm{CO}_{2}$ flux $\left(\mathrm{a}, \mathrm{mg} \mathrm{m}^{-2} \mathrm{~h}^{-1}\right)$, soil $\mathrm{CH}_{4}$ flux $\left(\mathrm{b}, \mathrm{mg} \mathrm{m}^{-2} \mathrm{~h}^{-1}\right)$, Litter $\left(\mathrm{c}, \mathrm{kg} \mathrm{m}^{-2}\right)$, soil surface temperature $\left(\mathrm{d}\right.$, $\left.{ }^{\circ} \mathrm{C}\right)$, and superficial soil moisture (d, \%). CN: Eucalyptus cultivation with conventional non-irrigated fertilization; CI: eucalyptus cultivation with irrigated conventional fertilization; FN: Eucalyptus cultivation with potential fertilization not irrigated; FI: Eucalyptus cultivation with irrigated potential fertilization. Means followed by upper case letters do not differ from treatments within the same position (R and IR) by the Tukey's test $(p<0.1)$. Means followed by lower case letters do not differ from each other regarding the position ( $R$ and IR) within the same treatment by the Tukey's test $(p<0.1)$. Comparisons in the Cerrado between treatments only.

differed $(p<0.05)$ from the Cerrado only for Non-labile-C (Figure 2). Although there is no difference between soil Labile-C stocks (layer 0-100 cm) this corresponds to $26.95,19.67,20.51,22.77$ and $24.63 \%$ of the TOC stocks of the Cerrado, CN, FN, CI and FI, respectively (Figure 2). When the Labile-C stock is evaluated by soil layer, the Cerrado differs from treatments under eucalyptus only in the topsoil $(0-10 \mathrm{~cm})$ (Table 2).

Table 2. Total carbon stocks ( $\mathrm{TOC}, \mathrm{Mg} \mathrm{ha}^{-1}$ ), Total nitrogen stock ( $\mathrm{TN}, \mathrm{Mg} \mathrm{ha}^{-1}$ ), C:N ratio and labile carbon stock (Labile-C, $\mathrm{Mg} \mathrm{ha}^{-1}$ ) in different soil layers under cultivation of eucalyptus and Cerrado.

\begin{tabular}{cccccc}
\hline \multicolumn{5}{c}{ TOC } \\
\hline Soil layers & Cerrado & CN & FN & CI & FI \\
\hline cm & & $\mathbf{M g ~ h a}^{-1}$ & & $43.51 \mathrm{a}$ \\
\hline $0-10$ & $47.08 \mathrm{a}$ & $48.66 \mathrm{a}$ & $55.75 \mathrm{a}$ & $39.94 \mathrm{a}$ & $38.07 \mathrm{a}$ \\
$10-20$ & $31.89 \mathrm{a}$ & $45.87 \mathrm{a}$ & $46.77 \mathrm{a}$ & $44.15 \mathrm{a}$ & $55.55 \mathrm{ab}$ \\
\hline $20-40$ & $40.88 \mathrm{~b}$ & $65.72 \mathrm{ab}$ & $73.33 \mathrm{a}$ & $63.41 \mathrm{ab}$ & $50.81 \mathrm{~b}$ \\
\hline $40-60$ & $34.52 \mathrm{c}$ & $56.81 \mathrm{ab}$ & $64.14 \mathrm{a}$ & $57.03 \mathrm{ab}$ & $80.23 \mathrm{a}$ \\
\hline $60-100$ & $39.06 \mathrm{~b}$ & $79.74 \mathrm{a}$ & $85.32 \mathrm{a}$ & $80.12 \mathrm{a}$ & \\
\hline
\end{tabular}


Table 2. Continued...

\begin{tabular}{|c|c|c|c|c|c|}
\hline \multicolumn{6}{|c|}{$\mathbf{T N}$} \\
\hline Soil layers & Cerrado & $\mathrm{CN}$ & FN & CI & FI \\
\hline $\mathrm{cm}$ & & & $\mathbf{M g ~ h a}^{-1}$ & & \\
\hline $0-10$ & $3.49 \mathrm{a}$ & $1.94 \mathrm{a}$ & $2.63 \mathrm{a}$ & $1.52 \mathrm{a}$ & $1.85 \mathrm{a}$ \\
\hline $10-20$ & $2.98 \mathrm{a}$ & $1.91 \mathrm{a}$ & $2.44 \mathrm{a}$ & $1.79 \mathrm{a}$ & $2.06 \mathrm{a}$ \\
\hline $20-40$ & $2.26 \mathrm{a}$ & $3.05 \mathrm{a}$ & $3.32 \mathrm{a}$ & $2.25 \mathrm{a}$ & $3.20 \mathrm{a}$ \\
\hline $40-60$ & $1.61 \mathrm{a}$ & $2.87 \mathrm{a}$ & $2.16 \mathrm{a}$ & $2.23 \mathrm{a}$ & $2.74 \mathrm{a}$ \\
\hline $60-100$ & $2.50 \mathrm{a}$ & $4.07 \mathrm{a}$ & $3.54 \mathrm{a}$ & $2.54 \mathrm{a}$ & $5.66 \mathrm{a}$ \\
\hline \multicolumn{6}{|c|}{ C:N ratio } \\
\hline Soil layers & Cerrado & $\mathrm{CN}$ & FN & CI & FI \\
\hline $\mathrm{cm}$ & & & $\mathrm{Mg} \mathrm{ha}^{-1}$ & & \\
\hline $0-10$ & $14.12 \mathrm{~b}$ & $24.96 \mathrm{ab}$ & $23.09 \mathrm{ab}$ & $33.49 \mathrm{a}$ & $23.83 \mathrm{ab}$ \\
\hline $10-20$ & $11.92 \mathrm{a}$ & $26.73 \mathrm{a}$ & $21.28 \mathrm{a}$ & $25.85 \mathrm{a}$ & $19.34 \mathrm{a}$ \\
\hline $20-40$ & $18.91 \mathrm{a}$ & $22.52 \mathrm{a}$ & $25.78 \mathrm{a}$ & $28.64 \mathrm{a}$ & $19.04 \mathrm{a}$ \\
\hline $40-60$ & $24.82 \mathrm{a}$ & $20.06 \mathrm{a}$ & $30.73 \mathrm{a}$ & $28.26 \mathrm{a}$ & $21.57 \mathrm{a}$ \\
\hline $60-100$ & $15.51 \mathrm{a}$ & $28.70 \mathrm{a}$ & $27.01 \mathrm{a}$ & $37.50 \mathrm{a}$ & $17.41 \mathrm{a}$ \\
\hline \multicolumn{6}{|c|}{ Labile-C } \\
\hline Soil layers & Cerrado & $\mathbf{C N}$ & FN & CI & FI \\
\hline $\mathrm{cm}$ & & & $\mathrm{Mg} \mathrm{ha}^{-1}$ & & \\
\hline $0-10$ & $16.30 \mathrm{a}$ & $9.83 \mathrm{~b}$ & $13.40 \mathrm{ab}$ & $9.84 \mathrm{~b}$ & $11.23 \mathrm{ab}$ \\
\hline $10-20$ & $8.11 \mathrm{a}$ & $8.98 \mathrm{a}$ & $10.20 \mathrm{a}$ & $11.08 \mathrm{a}$ & $9.59 \mathrm{a}$ \\
\hline $20-40$ & $8.66 \mathrm{a}$ & $18.20 \mathrm{a}$ & $15.23 \mathrm{a}$ & $15.53 \mathrm{a}$ & $15.47 \mathrm{a}$ \\
\hline $40-60$ & $7.04 \mathrm{a}$ & $10.25 \mathrm{a}$ & $11.91 \mathrm{a}$ & $11.52 \mathrm{a}$ & $12.71 \mathrm{a}$ \\
\hline $60-100$ & $12.02 \mathrm{a}$ & $11.15 \mathrm{a}$ & $15.99 \mathrm{a}$ & $16.85 \mathrm{a}$ & $17.05 \mathrm{a}$ \\
\hline
\end{tabular}

CN: Eucalyptus cultivation with conventional non-irrigated fertilization; CI: eucalyptus cultivation with irrigated conventional fertilization; FN: eucalyptus cultivation with potential fertilization not irrigated; FI: Eucalyptus cultivation with irrigated potential fertilization. Means followed by the same letter within the same layer do not differ by Tukey's test $(p<0.1)$.

\subsection{Carbon management index (CMI)}

Considering the $\mathrm{CMI}$ as an indicator of soil quality, when the soil profile is evaluated as a whole, $0-100 \mathrm{~cm}$ soil depth, the CMI of the treatments does not differ $(p>0.05)$ from each other (Figure 2).

\section{DISCUSSION}

\section{1. $\mathrm{CO}_{2}$ and $\mathrm{CH}_{4}$ fluxes}

The Cerrado provided the highest $\mathrm{CO}_{2}$ emissions from the soil to the atmosphere because it had the largest Labile-C stocks in the $0-10 \mathrm{~cm}$ soil layer, lower litter contribution, higher temperature (Figure 1 and Table 2), the action of the decomposing microorganisms and a more heterogeneous vegetal stratum in relation to eucalyptus.

The effect of soil cover on temperature reduction is a controlling factor of $\mathrm{CO}_{2}$ emission, once the microbial activity is accelerated with increases in soil temperature and the consequent higher $\mathrm{C}$ mineralization rate (Ussiri \& Lal, 2009).

For the soils under eucalyptus, the probable difference of the distribution of the root system in 


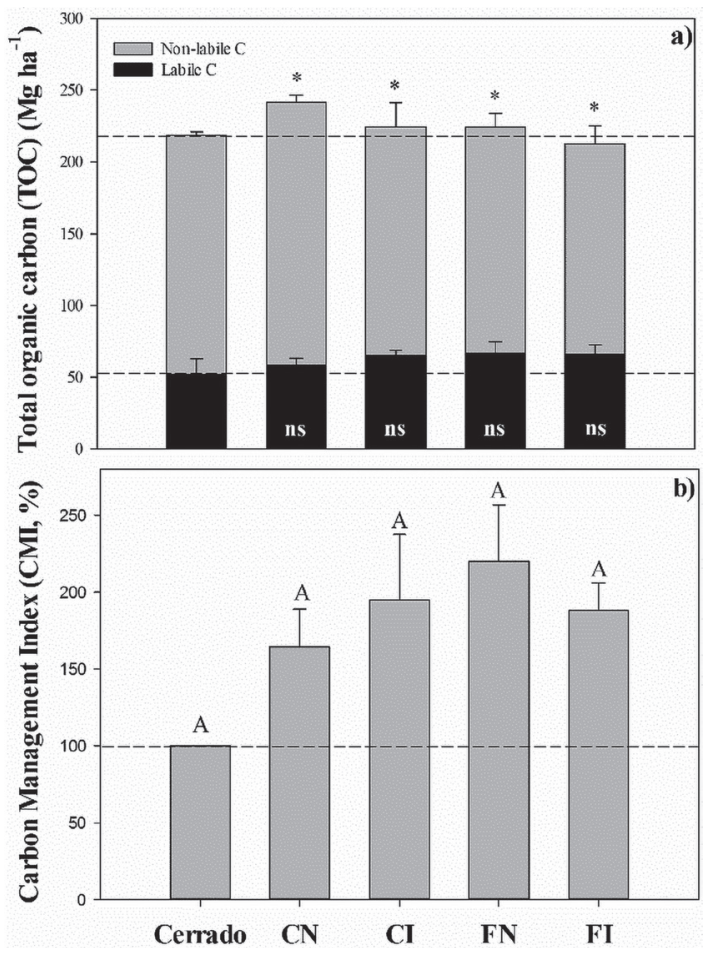

Figure 2. Total soil carbon stocks (a, TOC, $\mathrm{Mg} \mathrm{ha}^{-1}$ ) partitioned in Labile-C (a, $\left.\mathrm{Mg} \mathrm{ha}^{-1}\right)$ and Non-labile-C (a, $\mathrm{Mg}$ ha-1) in the layer 0-100 cm and soil carbon management index (b, CMI, \%) under eucalypt and Cerrado cultivation. $\mathrm{CN}$ : Eucalyptus cultivation with conventional non-irrigated fertilization; FN: Eucalyptus cultivation with potential fertilization not irrigated; CI: eucalyptus cultivation with irrigated conventional fertilization; FI: Eucalyptus cultivation with irrigated potential fertilization. ${ }^{*}$ Significant by the Dunnett's test $(p<0.05)$. Means followed by the same letter do not differ by Tukey's test $(p<0.05)$.

the soil profile led to changes in the $\mathrm{CO}_{2}$ and $\mathrm{CH}_{4}$ fluxes as well as the sampling position of the gases. Due to the lower water availability during cultivation, the $\mathrm{CN}$ and FN treatments possibly invested more in the root system, mainly verticalized, and presented higher $\mathrm{CO}_{2}$ efflux (autotrophic contribution) in the $\mathrm{R}$. The larger $\mathrm{C}$ partition to the roots (greater root/aerial part), almost always associated with the deepening of the root system, makes it possible to capture water in deeper soil layers (Gonçalves \& Passos, 2000). In order to avoid the lack of water, the plants use some strategies such as leaf and superficial roots loss, proliferation of deep roots (Reis et al., 2006), and osmotic adjustment for the maintenance of cellular turgor, which may result in lower soil humidity and, consequently, less power to oxidize $\mathrm{CH}_{4}$. However, for soils under irrigated eucalyptus (CI and FI), plants do not need to invest so much in the root system, since irrigation sprays the total area and the root system tends to be more horizontal (Sant'Ana et al.,
2012), which may justify the higher gas flux in the IR than in the R.

The limited availability of water also favors soil aeration and promotes the increase of the soil methanotrophic bacteria activity and the consequent soil $\mathrm{CH}_{4}$ influx. The process of $\mathrm{CH}_{4}$ influx is a consequence of the oxidation of $\mathrm{CH}_{4}$ by soil methanotrophic bacteria, under aerated conditions, use $\mathrm{CH}_{4}$ as source of energy and $\mathrm{C}$ (Lemer \& Roger, 2001; Saggar et al., 2008). Jacinthe \& Lal (2005), in a study on the $\mathrm{CH}_{4}$ oxidation in different crop management, concluded that soils that undergo management require decades to partially restore the $\mathrm{CH}_{4}$ oxidation capacity. They also report that the slow recovery of the ability to sequester $\mathrm{CH}_{4}$ is indicative of the damage to the niche of soil methanotrophic bacteria and that this damage is difficult to reverse. In the current study, it is evident that the potential soils under eucalyptus sequester $\mathrm{CH}_{4}$ from the atmosphere, as well as acting as a liquid drain of $\mathrm{CO}_{2}$ and $\mathrm{CH}_{4}$ of the atmosphere when it surpasses the Cerrado. 


\subsection{Soil carbon and nitrogen stocks}

In the soils under eucalyptus the presence of active irrigation to the soil microbiota favors the decomposition of the most labile compounds and fine roots and entails a probable positive "priming effect", which may be contributing to the lower TOC stocks (Fontaine et al., 2003) in surface and CI treatments. During the decomposition process, the microorganisms use the $\mathrm{C}$ in their metabolism and the excess can be released by respiration in the $\mathrm{CO}_{2}$ form (Vishwakarma et al., 2006).

For the soils under eucalyptus that did not receive irrigation, the largest TOC stocks are probably due to the investment in a deeper root system and a higher root/aerial part due to the need to exploit a larger soil volume to capture water. Reis et al. (1985) observed for Eucalyptus grandis that the root biomass accumulation was higher in a site of poorer quality (soil under water deficit) in relation to another of better quality (without water deficit). They also verified that in a condition of less availability of water and nutrients the trees tend to increase the $\mathrm{C}$ partition in the roots in order to increase their water acquisition surface.

The quantification of TOC stocks does not provide values that extrapolate for different management situations, sites, climates and soils (Nicoloso et al., 2008), which makes it necessary to divide into more sensitive compartments, such as Labile-C and Nonlabile-C. The largest Non-labile-C contribution to the soil TOC profile $(0-100 \mathrm{~cm})$ was probably due to two reasons: 1) Organo-mineral interactions that provide chemical protection to the TOC, since it refers to a well-developed Oxisol with clay content, high Fe and $\mathrm{Al}$ oxides; 2) The higher soil $\mathrm{C}: \mathrm{N}$ ratio observed under eucalyptus in the deeper layers, predominantly a more recalcitrant $\mathrm{C}$, which decomposition is difficult.

When the $0-10 \mathrm{~cm}$ soil layer is considered, the Cerrado sowed the largest Labile-C and TN stocks. This is due to the diversity and quality of the material contributed, once the composition of the Cerrado is given by an herbaceous stratum that coexists with sparse shrubs and trees, besides having grasses and species with lower C:N ratios in their composition, unlike the homogeneous material of eucalyptus crops. However, the soil under irrigated eucalyptus that received potential fertilization presented expressive values of TN stocks in the subsurface soil layers, explained by: 1) $\mathrm{N}$ leached in the soil profile through irrigation water may have interacted with soil TOC and rhizodeposition providing greater stabilization of C and $\mathrm{N}$ in the soil profile (Dijkstra et al., 2004). The higher amounts of $\mathrm{N}$ absorbed by eucalyptus plants, due to their high efficiency, increased the root biomass production allowing $\mathrm{C}$ and $\mathrm{N}$ stocks at higher soil depths (Stape et al., 2004).

The lower TN and larger TOC stocks in the $60-100 \mathrm{~cm}$ layer observed that soils under eucalyptus receiving conventional fertilization (independent of irrigation) provided a higher C:N ratio. This higher C:N (37.50 and 28.70) stoichiometry with the $\mathrm{O}_{2}$ limitation in depth gives $\mathrm{CI}$ and $\mathrm{CN}$ a more recalcitrant $\mathrm{C}$ and less accessible to the microbial action, favoring the soil C accumulation (Lamparter et al., 2009). In the current study, for soils under eucalyptus that received potential fertilization (irrespective of irrigation) $\mathrm{N}$ is probably carried (as previously mentioned) to the deeper layers of the soil and promotes a lower C:N ratio.

\subsection{Carbon Management Index (CMI)}

$\mathrm{CMI}$ is used as an indicator of the impact of land use and management practices on soil $\mathrm{C}$ levels and quality. The soil surface layer, the Cerrado stratum, for reasons already discussed, favors the best quality of the COS (Portugal et al., 2008). However, when the soil profile is considered as a whole, eucalyptus cultivation recovers the SOC quality as it provides greater soil C stocks in the deeper layers. This probably has a more developed root system that favors the soil exploration in depths where the action of the microorganisms is restricted favoring the $\mathrm{C}$ accumulation. In addition, the cultivation of eucalyptus contributes to large amounts of litter fall to the soil and provides lower emissions of gases to the atmosphere.

\section{CONCLUSIONS}

After 7 years of eucalyptus cultivation, water availability (irrigation management) had a higher effect on soil C stocks (profile $1 \mathrm{~m}$ ) in relation to nutrient availability (fertilization). 
Eucalyptus soils (after 7 years of different fertilization and irrigation managements) were more efficient in C stocks in depth (profile $1 \mathrm{~m}$ ) in relation to the native Cerrado, acting as a liquid drain of $\mathrm{CO}_{2}$ and $\mathrm{CH}_{4}$ of the atmosphere.

\section{SUBMISSION STATUS}

Received: 2 June, 2017

Accepted: 24 Nov., 2018

\section{CORRESPONDENCE TO}

\section{Ricardo Fialho}

Universidade Federal de Viçosa (UFV), Av. Peter Henry Rolfs, s/n, CEP 36570-000, Viçosa, MG, Brasil e-mail: ricardocfialho@gmail.com

\section{FINANCIAL SUPPORT}

Conselho Nacional de Desenvolvimento Científico e Tecnológico (CNPq), Coordenação de Aperfeiçoamento de Pessoal de Nível Superior (Capes), Vallourec Florestal.

\section{REFERENCES}

Bernal B, McKinley DC, Hungate BA, White PM, Mozdzer TJ, Megonigal JP. Limits to soil carbon stability; deep, ancient soil carbon decomposition stimulated by new labile organic inputs. Soil Biology \& Biochemistry 2016; 98: 85-94. 10.1016/j.soilbio.2016.04.007

Blair G, Lefroy R, Lisle L. Soil carbon fractions based on their degree of oxidation, and the development of a carbon management index for agricultural systems. Australian Journal of Agricultural Research 1995; 46(7): 1450-1459. 10.1071/AR9951459

Dijkstra FA, Hobbie SE, Knops JMH, Reich PB. Nitrogen deposition and plant species interact to influence soil carbon stabilization Ecology Letters 2004; 7(12): 11921198. 10.1111/j.1461-0248.2004.00679.x

Ellert BH, Bettan JR. Calculation of organic matter and nutrients stored in soils under contrasting management regimes. Canadian Journal of Soil Science 1995; 75(4): 529-538. 10.4141/cjss95-075

Fialho RC, Zinn YL. Changes in soil organic carbon under Eucalyptus plantations in Brazil: a comparative analysis. Land Degradation \& Development 2014; 25(5): 428-437. 10.1002/ldr.2158
Fontaine S, Mariotti A, Abbadie L. The priming effect of organic matter: a question of microbial competition? Soil Biology and Biochemistry 2003; 35(6): 837-843. 10.1016/ S0038-0717(03)00123-8

Forrester DI, Bauhus J, Cowie AL. Carbon allocation in a mixed-species plantation of Eucalyptus globulus and Acacia mearnsii. Forest Ecology and Management 2006; 233(2-3): 275-284. 10.1016/j.foreco.2006.05.018

Gatto A, Barros NF, Novais RF, Silva IR, Leite HG, Leite FP et al. Estoques de carbono no solo e na biomassa em plantações de eucalipto. Revista Brasileira de Ciência do Solo 2010; 34(4): 1069-1079. 10.1590/S010006832010000400007

Gatto A, Barros NF, Novais RF, Silva IR, Leite HG, Villani EMA. Estoque de carbono na biomassa de plantações de eucalipto na região Centro-leste do estado de Minas Gerais. Revista Árvore 2011; 35(4): 895-905. 10.1590/ S0100-67622011000500015

Gonçalves MR, Passos CAM. Crescimento de cinco espécies de eucalipto submetidas a déficit hídrico em dois níveis de fósforo. Ciência Florestal 2000; 10(2): 145161. 10.5902/19805098488

Hansen MC, Potapov PV, Moore R, Hancher M, Turubanova SA, Tyukavina A et al. High-resolution global maps of forest cover change. Science 2013; 342(6160): 850-853. 10.1126/science. 1244693

Instituto Nacional de Pesquisas Espaciais - Inpe. Taxas anuais do desmatamento: 1988 até 2014. 2014 [cited 2015 Apr. 1]. Available from: https://bit.ly/2sdFkw2

Intergovernmental Panel on Climate Change - IPCC. Fifth assessment report. Cambridge: Cambridge University Press; 2014.

Jacinthe PA, Lal R. Labile carbon and methane uptake as affected by tillage intensity in a Mollisol. Soil and Tillage Research 2005; 80(1-2): 35-45. 10.1016/j.still.2004.02.018

Lai Z, Zhang Y, Liu J, Wu B, Qin S, Fa K. Fine-root distribution, production, decomposition, and effect on soil organic carbon of three revegetation shrub species in northwest China. Forest Ecology and Management 2016; 359: 381-388. 10.1016/j.foreco.2015.04.025

Lamparter A, Bachmann J, Goebel MO, Woche SK. Carbon mineralization in soil: impact of wetting-drying, aggregation and water repellency. Geoderma 2009; 150(34): 324-333. 10.1016/j.geoderma.2009.02.014

Lemer J, Roger P. Production, oxidation, emission and consumption of methane by soils: a review. European Journal of Soil Biology 2001; 37(1): 25-50. 10.1016/S11645563(01)01067-6

Li S, Han S, Zhang Y. Foliar decomposition in a broadleafmixed Korean pine (Pinus koraiensis Sieb. Et Zucc) plantation forest: the impact of initial litter quality and the decomposition of three kinds of organic matter fraction 
on mass loss and nutrient release rates. Plant and Soil 2007; 295(1-2): 151-167. 10.1007/s11104-007-9272-y

Nicoloso RS, Lovato T, Amado TJC, Bayer C, Lanzanova ME. Balanço do carbono orgânico no solo sob integração lavoura-pecuária no sul do Brasil. Revista Brasileira da Ciência do Solo 2008; 32(4): 2425-2433. 10.1590/S010006832008000600020

Portugal AF, Jucksch I, Schaefer CEGR, Wendling B. Determinação de estoques totais de carbono e nitrogênio e suas frações em sistemas agrícolas implantados em argissolo vermelho-amarelo. Revista Brasileira de Ciência do Solo 2008; 32(5): 2091-2100. 10.1590/S010006832008000500030

Rasse DP, Rumpel C, Dignac MF. Is soil carbon mostly root carbon? Mechanisms for a specific stabilisation. Plant and Soil 2005; 269(1-2): 341-356. 10.1007/s11104-004-0907-y

Reis GG, Reis mgF, Fontan ICI, Monte MA, Gomes NA, Oliveira CHR. Crescimento de raízes e da parte aérea de clones de híbridos de Eucalyptus grandis $\times$ Eucalyptus urophylla e de Eucalyptus camaldulensis $\times$ Eucalyptus spp submetidos a dois regimes de irrigação no campo. Revista Árvore 2006; 30(6): 921-931. 10.1590/S010067622006000600007

Reis MGF, Kimmins JP, Resende GC, Barros NF. Acúmulo de biomassa em uma sequência de idade de Eucalyptus grandis plantado no Cerrado em duas áreas com diferentes produtividades. Revista Árvore 1985; 9(2): 149-162.

Saggar S, Tate KR, Giltrap DL, Singh J. Soil-atmosphere exchange of nitrous oxide and methane in New Zealand terrestrial ecosystems and their mitigation options: a review. Plant and Soil 2008; 309(1-2): 25-42. 10.1007/ s11104-007-9421-3

Sant'Ana JAV, Coelho EF, Faria MA, Silva EL, Donato SLR. Distribuição de raízes de bananeira "prata-anã" no segundo ciclo de produção sob três sistemas de irrigação. Revista Brasileira de Fruticultura 2012; 34(1): 124-133. 10.1590/S0100-29452012000100018

Schmidt MWY, Torn MS, Abiven S, Dittmar T, Guggenberger G, Janssens IA et al. Persistence of soil organic matter as an ecosystem property. Nature 2011; 478: 49-56. 10.1038/nature10386

Shang C, Tiessen H. Organic matter lability in tropical Oxisol: evidence from shifting cultivation, chemical oxidation, particle size, and magnetic fractionations. Soil Science 1997; 162(11): 795-807.
Smith KA, Conen F. Measurement of trace gases, I: gas analysis, chamber methods, and related procedures. In: Smith KA, Cresser MS, editors. Soil and environmental analysis: modern instrumental techniques. 3rd ed. New York: CRC Press; 2004. p. 433-476.

Stape JL, Binkley D, Ryan MG. Eucalyptus production and the supply, use and efficiency of use of water, light and nitrogen across a geographic gradient in Brazil. Forest Ecology and Management 2004; 193(1-2): 17-31. 10.1016/j. foreco.2004.01.020

Stape JL, Binkley D, Ryanc MG, Fonseca S, Loos RA, Takahashi EN et al. The Brazil Eucalyptus Potential Productivity Project: influence of water, nutrients and stand uniformity on wood production. Forest Ecology and Management 2010; 259(9): 1684-1694. 10.1016/j. foreco.2010.01.012

Turner J, Lambert MJ, Johnson DW. Experience with patterns of change in soil carbon resulting from forest plantation establishment in eastern Australia. Forest Ecology and Management 2005; 220(1-2): 259-269. 10.1016/j.foreco.2005.08.025

Ussiri AN, Lal R. Long-term tillage effects on soil carbon storage and carbon dioxide emissions in continuous corn cropping system from an alfisol in Ohio. Soil Tillage Research 2009; 104(1): 39-47. 10.1016/j.still.2008.11.008

Vishwakarma K, Sharma S, Kumar N, Upadhyay N, Devi $S$, Tiwari A. Contribution of microbial inoculants to soil carbon sequestration and sustainable agriculture. In: Singh DP, Singh HB, Prabha R, editors. Microbial inoculants in sustainable agricultural productivity: functional applications. New Delhi: Springer; 2016. v. 2. p. 101-113. 10.1007/978-81-322-2644-4_7

Zinn YL, Lal R, Resck DVS. Texture and organic carbon relations described by a profile pedotransfer function for Brazilian Cerrado soils. Geoderma 2005; 127(1-2): 168-173. 10.1016/j.geoderma.2005.02.010

Zinn YL, Lal R, Resck DVS. Eucalypt plantation effects on organic carbon and aggregation of three differenttextured soils in Brazil. Soil Research 2011; 49(7): 614-624. 10.1071/SR11264

Zinn YL, Resck DVS, Silva JE. Soil organic carbon as affected by afforestation with Eucalyptus and Pinus in the Cerrado region of Brazil. Forest Ecology and Management 2002; 166(1-3): 285-294. 10.1016/S03781127(01)00682-X 